\title{
Transformational Leadership Characteristics Necessary For Today's Leaders In Higher Education
}

Lloyd Moman Basham, Texas A\&M University-Commerce, USA

\begin{abstract}
This study is concerned with the traits and characteristics of presidents of institutions of higher education who are considered transformational leaders. The study adds current data to the published and perceived characterization of leaders in higher education and their approaches to changing the learning environment at their institutions. This study addresses the significance and current widespread appeal of transformational leadership and its practical application to higher education; but equally important, it profiles the group and individual qualities that are necessary for individuals to have, as their acumen, in order to introduce a climate of change utilizing transformational leadership.
\end{abstract}

Keywords: Transformation; Leadership; Higher Education; Presidents

\section{OVERVIEW OF LEADERSHIP AND ITS APPLICATION TO EDUCATION}

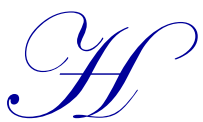

istorically, organizations have been viewed as learning systems in which success depends on the ability of leaders to become direction-givers and on the organization's capacity for continuously learning (Garrat, 1987). Transformational leaders tend to have the attributes to learn across their specialist discipline. Transactional leaders are usually at the top of their functional specialty and have limited perspective to see that change is needed and what the consequences may be for continuing the same practices (Bass, 2003).

Elements of quality leadership are existent within every functional activity with representatives serving in any capacity that can influence change. Quality leadership is demonstrated if effective results are recognized and realized. Traits that define effective leadership are included in either a category of group or individual. Group traits include collaboration, shared purpose, disagreement with respect, division of labor, and a learning environment. Individual traits include self-knowledge, authenticity/integrity, commitment, empathy/understanding of others, and competence (Astin \& Astin, 2000) as shown in Table 1.

Table 1: What is Effective Leadership?

\begin{tabular}{|c|c|}
\hline Group Qualities & Individual Qualities \\
\hline $\begin{array}{l}\text { Shared purpose - reflects the shared aims and values of the } \\
\text { group's members; can take time to achieve. }\end{array}$ & $\begin{array}{l}\text { Commitment - the passion, intensity, and persistence that supplies } \\
\text { energy, motivates individuals, and drives group effort. }\end{array}$ \\
\hline $\begin{array}{l}\text { Collaboration-an approach that empowers individuals, engenders } \\
\text { trust, and capitalizes on diverse talents. }\end{array}$ & $\begin{array}{l}\text { Empathy-the capacity to put oneself in another's place; requires } \\
\text { the cultivation and use of listening skills. }\end{array}$ \\
\hline $\begin{array}{l}\text { Division of labor-requires each member of the group to make a } \\
\text { significant contribution to the overall effort. }\end{array}$ & $\begin{array}{l}\text { Competence-the knowledge, skill, and technical expertise } \\
\text { required for successful completion of the transformation effort. }\end{array}$ \\
\hline $\begin{array}{l}\text { Disagreement with respect-recognizes that disagreements are } \\
\text { inevitable and should be handled in an atmosphere of mutual trust. }\end{array}$ & $\begin{array}{l}\text { Authenticity-consistency between one's actions and one's most } \\
\text { deeply felt values and beliefs. }\end{array}$ \\
\hline $\begin{array}{l}\text { A learning environment-allows members to see the group as a } \\
\text { place where they can learn and acquire skills. }\end{array}$ & $\begin{array}{l}\text { Self-knowledge - awareness of the beliefs, values, attitudes, and } \\
\text { emotions that motivate one to seek change. }\end{array}$ \\
\hline
\end{tabular}




\section{Transformational Leadership}

Transformational leadership is the current focus of concepts relating to organizational leadership. These concepts are based on vision statements that provide the directional path for the organization. In addition, the vision statement should be supplemented with a mission statement that energizes and inspires all members of the organization as they pursue obtainable organizational objectives. The vision and mission statements establish the long term goals of the organization and are the basis for the organization's strategy and identification of methods for implementation of the strategy.

Transformational leaders who develop and communicate a vision and a sense of strategy are those who "find clear and workable ways to overcome obstacles, are concerned about the qualities of the services their organization provide, and inspire other members to do likewise" (Swail, 2003, p. 14). Transformational leaders encourage development and change.

Historical definitions of transformational leaders have depicted the leaders as heroes, with accompanying charismatic personalities expressing and promoting a mission of major organizational change. Heightened scholarly attention surfaced in the 1990s addressing the merits and theories of transformational leadership. This increased interest by society in transformational leadership was driven by two major undercurrents. The first was the evolution of cynicism and disillusionment with the very idea of leadership and the changing climates of opinion endorsing various versions or types of leadership. The second was the constantly changing leadership styles that were the "order of the day" as attempts to adapt to the wider cultural and economic shifts and development occurring in society. Therefore, interest and research in transformational leadership began to boom (Bass \& Avolio, 1993). The transformational leader is still a long way from being the leader for every situation and, as a result, few empirically documented case examples of capturing the transformational leaders' acumen exist.

Transformational leadership is value driven. The leader sets high standards and purposes for followers, engaging them through inspiration, exemplary practice, collaboration, and trust. Transformation leadership aims at responding to change quickly and at bringing out the best in people. Such leadership is change-oriented and central to the development and survival of organizations in times of environmental turmoil, when it is necessary to make strategic changes to deal with both major threats and opportunities. It derives its power from shared principles, norms, and values. Leaders who encourage and support transformation pay specific attention to intellectual stimulation. (Ramsden, 1998; Caldwell \& Spinks, 1999; Bass \& Avolio, 1993).

The transformational leader may be needed in the scholarly community (Bass \& Avolio, 1990; Leithwood, 1992, Sergiovanni, 1990; Silins, 1994). A key factor is the introduction of entrepreneurialism to the public sector. This is due to higher education institutions attempting to adapt to the economic and organizational shifts in their environment. The last two decades declining support for higher education from its traditional sources of funding emphasizes this point. As a result, major short term goals have been established, and day-to-day focus has shifted to an environment of institution marketing or business development, and the focus is not on students.

Transformational leadership is essential within higher education so that adaptation can be completed to meet the constantly changing economic and academic environment. Leaders who encourage and support transformation leadership share power, are willing to learn from others, and are sensitive to each team member's needs for achievement and growth (Gous, 2003).

Transformational leadership draws from deeply held personal value systems. Transformational leaders bring followers together to pursue collective ambitions by expressing and disseminating their personal standards. While transactional leadership can most certainly bring about constructive outcomes within an organization, transformational leadership is held to promote performance beyond expectations by drawing from charisma, consideration, motivation, and stimulation (Carlson \& Perrewe, 1995).

This current study highlights the identity of effective leadership in higher education by applying a matrix of group qualities and individual qualities to an expert panel of leaders in higher education. A Delphi study was used to obtain consensus and to determine if leadership utilized has in fact been effective or can be effective (Table 1). 


\section{STATEMENT OF THE PROBLEM}

Significant changes in higher education have occurred due to taxpayer backlash (Alexander, 2000), the rapid growth of the Internet, increasing globalization of higher education, economic shifts in the demographics of society, and economic commerce. These influential factors are creating the need for a new definition and approach to the management of higher education institutions. Should presidents of institutions of higher education be utilizing transformational leadership management practices and concepts to benefit the stakeholders of higher education? Secondly, what leadership qualities are necessary for a university president to develop a vision and well-designed strategy to overcome funding limitations and to develop alternative and workable plans in a university setting? This study attempts to provide answers to these questions.

\section{METHODOLOGY AND RESEARCH DESIGN}

A Delphi study was used to obtain consensus and to determine if leadership utilized has in fact been effective or can be effective (Table 1). This Delphi study began with selecting 300 university presidents from both private and public higher education accredited institutions in the United States from the $25^{\text {th }}$ anniversary Higher Education Directory®. These selections were made utilizing a random numbering selection criterion from the Random Number Generator in Excel ${ }^{\mathrm{TM}}$ software. Excluded from this selection were university presidents that represented higher education institutions classified as technical schools.

An invitation letter was sent to these 300 selectees with a positive response from 52 university presidents (representing a 17\% acceptance). This broad-based representation became the expert panel for the initiation of round one of the Delphi study. The expert panel provided input to 41 distinct indicators that included a list of concerns, issues, management practices and concepts, and effective leadership qualities. These indicators were force rated through three rounds of surveys to determine the level of agreement and consensus determined from medians and interquartile ranges for each indicator.

The panel was asked to refine the list by the following methods:

1. indicating the relative significance of each major concern on the rating scale by force ranking

2. adding new concerns or practices and concepts to the list.

The result of the first round was $100 \%$ participation.

Round 2 had a response rate of $70 \%$ of the expert panel resulting in 36 panelists participating. Reasons for 10 of the panelists not responding were the retirement of 3 , the resignations of 3 , the deaths of 2 , the transfer of one panelist to another institution, and the request of one panelist to withdraw from participation. No reason was given 6 of the panelists who ceased to participate and did not response to multiple attempts of communication follow-up.

Round 3 has a response rate of 97\%, (35 panel members), of the adjusted panel from Round 3 of 36 participants. This was due to one panelist requesting to be removed from the panel.

\section{DISCUSSION OF DELPHI RESULTS}

The data from the expert panel were analyzed using two criteria, which were level of agreement and consensus. The level of agreement for each of the 41 indicators was expressed using the median as the unit of measure. Supplementing the median was the mean (average) and both taken together provided support for determining the level and order of importance. The level of consensus of each of the 41 indicators was expressed as the interquartile range. Supplementing the interquartile range was the standard deviation which, taken together, provided support for determining the level of consensus. The priority ranks (level of agreement) were combined with the degree of consensus to determine the overall importance of the major concerns.

Final ratings resulted in $25(61 \%)$ of the 41 indicators receiving a median rating of 6 or less, indicating that the panelists agreed or strongly agreed the indicator was applicable, and 23 indicators (56\%) reached a level of 
statistical consensus with an IQR of 2 or less. Indicators reaching the highest and strongest level of consensus were 8 representing $20 \%$ of the total indicators.

\section{FINDINGS, CONCLUSION, AND LIMITATIONS}

Based on the findings of this study, the following conclusions were drawn:

- The climate and relationships with an atmosphere and environment of transformational leadership within higher education requires further research.

- $\quad$ The distinction within transformational leadership practices and concepts in higher education may not be as clear as traditionally believed.

- University presidents recognize the critical need for devoting time in providing all stakeholders of their higher education institution with a vision, purpose, and with values that result in a clear and consistent direction.

- University presidents recognize that establishing an environment of excellence in the performance of their institution for higher education inspires trust in their leadership as well as energizes the complete organization including faculty, staff, and students.

- University presidents realize that their major challenge in introducing change at their institutions of higher education is the traditional and historical structures of culture with its accompanying policies and procedures.

- Transformational leadership practices and concepts will have to be applied at an institution of higher education to ensure change due to the reluctance of tenured faculty and staff to consider changes due to personal impact.

- The situation and environment of reduction in state and/or government funding to higher education will require critical application of transformational leadership practices and concepts to ensure that an institution of higher education achieves its purpose of learning.

- $\quad$ For an institution of higher education to be successful, its president must have the individual quality of commitment demonstrated with passion, intensity, and persistence which will supply the energy and momentum, to motivate and stimulate the stakeholders to strive toward a group effort.

- A university president's competency in knowledge, leadership skills, and technical expertise is necessary to ensure the successful completion of a transformational effort.

- The attribute of authenticity must reside within the university president's acumen so that there is consistency between his/her actions and most deeply felt values and beliefs.

\section{ACTIONABLE CONCLUSIONS}

- Updating and refinement of institutions Strategic Plan which should include imperatives. These imperatives should be driven down into the Colleges and individual departments.

- Implementing a quality program of Six Sigma and subsequent application for the Malcolm Baldridge award.

- Immediate update of all policies and procedures to ensure that applicability is possible for current existing climate and environment.

- Implementing a rigorous program of post tenure review with high standards applied consistently and uniformly to all members of the faculty.

- An extensive embracement with Alumni and stakeholders in developing a participative Institution Development program.

- $\quad$ Contracts for presidents should be limited to 5 years with only one renewal.

- University search committees should begin requiring candidates for the President's position to have prior business and practical experience in addition to academia.

The following limitations pertain to this study: 
- $\quad$ Research did not include management theory, as presented in Business colleges by educators or by management practitioners or theorists, prior to 1965.

- $\quad$ Restrictive boundaries were placed by the researcher on phenomena relating to institutions of higher education whose purpose is the development of technical skills, commonly referred to as technical schools, even though many of these have now become accredited and offer both bachelor and master's degrees.

- $\quad$ Restrictive boundaries were placed by the researcher on training schools developed by corporate America whose programs may have become accredited to offer degrees.

- $\quad$ The selection of the Delphi method in itself imposed limitations relating to the kind of communication process that was utilized. A major challenge included the selection of the people with expertise in the problem and where they might be located.

\section{AUTHOR INFORMATION}

Dr. Lloyd M. Basham: Professor (BBA, Accounting, MBA, M.A., International Management, Ed. D, Leadership is Department Head and Assistant Professor of Marketing and Management in the College of Business and Entrepreneurship at Texas A \& M University - Commerce. His practical experiences are as an early corporate America executive retiree with 30 years of corporate background. These associations were with Fortune 200 firms in the Computer/Telecommunications -Motorola and Nortel - and Security/Risk and Financial Services -The Pittston Company- industries in various executive positions both in financial and operational capacities. E-mail: Lloyd.Basham@tamuc.edu

\section{REFERENCES}

1. Alexander, F.K. (2000). The changing face of accountability. The Journal Of Higher Education, 71(4), 411-431.

2. Astin, A.W., \& Astin, H.S. (2000). Leadership Reconsidered: Engaging Higher Education in Social Change. Battle Creek, MI: W.K. Kellogg Foundation.

3. Bass, B.M., \& Avolio, B.J. (1990). Transformational leadership manual for multifactor leadership questionnaire. Palo Alto, CA: Consulting Psychologists Press.

4. $\quad$ Bass, B.M., \& Avolio, B.J. (1993). Transformational leadership and organizational culture. Public Administration Quarterly, 17, 50.

5. Bass, B. M., Avolio, B.J., Jung, D.I., \& Berson, Y. (2003). Predicting Unit Performance by Assessing Transformational and Transactional Leadership. Journal of Psychology, 88 (2), 207-218.

6. Caldwell, B.J., \& Spinks, J.M. (1999). Beyond the self-managing school Student Outcomes and the Reform of Education Series. London: Falmer Press.

7. Carlson, D. S. \& Perrewe, P. L. (1995). Institutionalization of Organizational Ethics Through Transformational Leadership. Journal of Business Ethics, 14(1), 829-839.

8. Garrat, B. (1987). The learning organization and the need for directors who think. New York: Harper Collins.

9. Gous, M. (2003). Leadership in support of learning for an unknown future. Paper presented at the HERTDSA 2003 conference. Retrieved March 26, 2005, from http://surveys.canterbury.ac.nz/herdsa03/pdfsnon/N1071.pdf.

10. Leithwood, R.A. (1992). The move toward transformational leadership, Educational Leadership, 49 (5), 812.

11. Sergiovanni, T.J. (1990). Supervision: A redefinition, ( ${ }^{\text {th }}$ ed.). New York: McGrath.

12. Silins, H.C. (1994). The relationship between transformational leadership and school improvement outcomes. School Effectiveness and School Improvement, 5(3), 165-184.

13. Swail, W.S. (2003, January/February). Responding responsibility. Change, (p.10-19). 


\section{NOTES}

